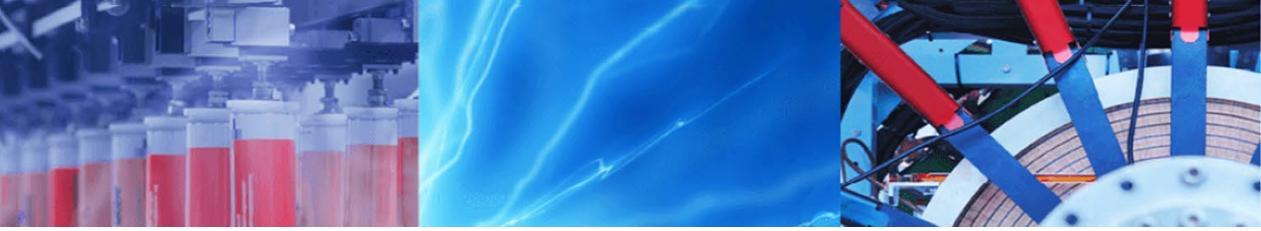

Research Article

\title{
Heavy metals in surface sediments of Lake Naivasha, Kenya: spatial distribution, source identification and ecological risk assessment
}

\author{
Grace Olando $^{1} \cdot$ Lydia A. Olaka ${ }^{2,3}$ (D) Philip O. Okinda ${ }^{4} \cdot$ Paul Abuom $^{1}$
}

Received: 28 September 2019 / Accepted: 9 January 2020 / Published online: 28 January 2020

(C) The Author(s) 2020 OPEN

\begin{abstract}
Heavy metals retained in sediments pose a threat to aquatic ecosystem and society. Knowledge of the status and sustainability of lake sediment in areas undergoing rapid economic development is scarce, and yet it is required in order to achieve the United Nations Sustainable Development goals. We investigated heavy metal concentration in Lake Naivasha sediments using enrichment factor, geoaccumulation index, pollution load index (PLI), risk index (RI) and multivariate statistics to determine metal accumulation, distribution and the lake's pollution status. Sediments sampling followed a grid approach, and seven heavy metals: $\mathrm{Co}, \mathrm{Cr}, \mathrm{Cu}, \mathrm{Mn}, \mathrm{Pb}, \mathrm{Zn}$ and $\mathrm{Fe}$, were analyzed in total; concentrations were determined using portable X-ray fluorescence. The distribution maps were interpolated in a GIS platform, and the toxicity risk of sediments was determined. The concentrations of elements in the sediments are in the following decreasing order: $\mathrm{Fe}>\mathrm{Mn}>\mathrm{Zn}>\mathrm{Cu}>\mathrm{Cr}>\mathrm{Co}>\mathrm{Pb}$. High concentration of heavy metals is found in the southern shoreline and east of the lake due to shoreline discharge and agricultural effluents drained into the lake and shoreline transgression. $\mathrm{Pb}$ and $\mathrm{Zn}$ are of anthropogenic origin, while $\mathrm{Cu}$ and $\mathrm{Mn}$ originate from both natural and anthropogenic sources and $\mathrm{Fe}$ and $\mathrm{Co}$ are from natural sources. In addition, the mean toxicity decreases in the order: $\mathrm{Cu}>\mathrm{Fe}>\mathrm{Co}>\mathrm{Pb}>\mathrm{Zn}>\mathrm{Mn}>\mathrm{Cr}$. The PLI values were above one $(>1)$, indicating progressive deterioration of the sediment quality. Though the overall ecological risk of the lake is low to moderate (RI 36.73-60.51), hotspots of pollution should be marked for intervention. This assessment also helps to fill the knowledge gap required to formulate the right policies in implementing sustainable development goals in similar lakes.
\end{abstract}

Keywords Pollution · Ecological risk · Aquatic ecosystem · GIS · SDGs · Africa

\section{Introduction}

More than half of the world's freshwater lakes face massive ecological threats due to contamination by toxic substances, due to the global increase in use of chemicals in industries, agricultural modernization, mining and urbanization [1-4]. Less than $0.1 \%$ of the metals are actually dissolved in the water, and more than $99.9 \%$ are stored in sediments [5]. Sediments can either release metals to the water column or serve as a source of metals for bioaccumulation and biomagnification in aquatic organisms such as benthic fauna and fish and cause loss of desirable biodiversity [6-9]. The concentrations of heavy metals in sediment fraction are governed by the physicochemical

Electronic supplementary material The online version of this article (https://doi.org/10.1007/s42452-020-2022-y) contains supplementary material, which is available to authorized users.

$\triangle$ Lydia A. Olaka, lydiaolaka@uonbi.ac.ke| 'Department of Environmental Sciences, Maseno University, P.O. Box 333, Maseno 40105, Kenya. ${ }^{2}$ Department of Geology, University of Nairobi, P.O. Box 30197, Nairobi, Kenya. ${ }^{3}$ Stellenbosch Institute for Advanced Study, Wallenberg Research Centre at Stellenbosch University, Stellenbosch 7600, South Africa. ${ }^{4}$ Department of Chemistry, Maseno University, P.O. Box 333, Maseno 40105, Kenya. 
parameters of the lake, such as $\mathrm{pH}$, sediment fraction and redox conditions $[10,11]$. Changes in these conditions can present a potential health risk to a population through remobilization of the pollutants to the sediment-water interface [12-14].

Due to the negative impacts of heavy metals on aquatic ecosystems, majority of studies done on this topic in the last decade have been in countries undergoing rapid industrial growth such as China, India and Brazil [15-20]. They highlight an increase in various anthropogenic sources of heavy metals. The studies also show that pollution intensity correlates with distance from source. The studies have employed various indices to assess heavy metal contamination, discriminate sources and the associated ecological risk. These include commonly used geochemical normalization approaches such as the enrichment factor (EF) and geoaccumulation index $\left(I_{\text {geo }}\right)$ [21-26]. The potential toxicity and risks are assessed using indices such as sedimentary quality guidelines, potential ecological risk index and pollution load index [17, 23, 25, $27,28]$. These have highlighted that sediments of lakes, with varied morphometric and lake zonation, need spatially resolved assessment approaches to enable proper management interventions. Combing these indices with GIS spatial assessments will help develop needed targeted intervention plans.

Lake Naivasha is an important East African rift lake, with high species diversity and providing a variety of ecosystem services. Over $35 \%$ of flowers into Europe are grown within its catchment. However, ecological changes in the lake in the last two decades coincide with increase in horticultural farming [29-33]. Earlier, increase in sediment load to the lake is linked to commercial farming during British colonization [34], and subsequent, high concentrations of heavy metals in sediments, water and fishes have been reported [35-38]. The methodologies employed in these studies were diverse in terms of sampling, depth, density, toxic metals detected and risk assessment. A spatially comprehensive risk assessment of all the lake zones is needed to identify hotspots and help support environmental regulation in Kenya. Thus, the specific objectives of this study are (1) to investigate the spatial distribution and concentration of seven heavy metals ( $\mathrm{Co}, \mathrm{Cr}, \mathrm{Cu}, \mathrm{Fe}, \mathrm{Mn}, \mathrm{Pb}, \mathrm{Zn}$ ) in surface sediments of Lake Naivasha, (2) to identify the possible sources of these metals and (3) to determine the ecological risk posed by the selected heavy metals in the lake and identify hotspots.

\section{Materials and methods}

\subsection{Study area}

Lake Naivasha is a freshwater lake on the floor of the central Kenya Rift, located between latitudes $0^{\circ} 42^{\prime}-0^{\circ} 50^{\prime} \mathrm{S}$ and longitudes $36^{\circ} 16^{\prime}-36^{\circ} 26^{\prime} \mathrm{E}$ (Fig. 1). The lake spans about $160 \mathrm{~km}^{2}$ in surface area, roughly circular in shape and comprises three connected water bodies; main lake,

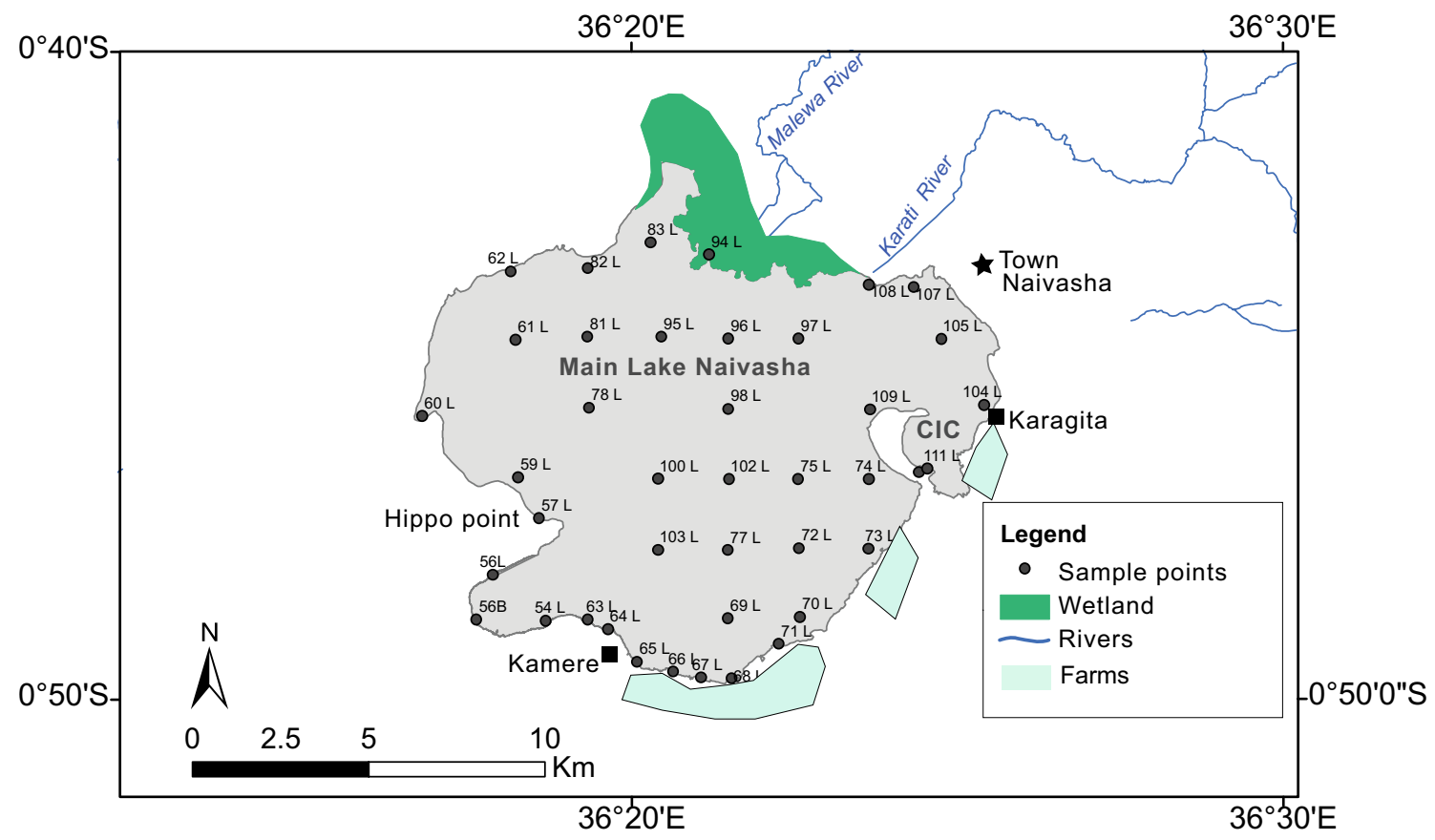

Fig. 1 Map of Lake Naivasha showing sampling points 
Oloiden and crescent island lake whose depths are $7 \mathrm{~m}$, $6.5 \mathrm{~m}$ and $15 \mathrm{~m}$, respectively [39]. The lake is drained by four rivers flowing from the high elevation escarpments, but only two (Malewa and Gilgil rivers) draining the north and northeastern side of the catchment feed the lake directly through the wetland in the north. The other two rivers (Marmanet and Karati) terminate before reaching the lake. There is no surficial river outlet, and the presence of subsurface outflows in the north and south of the lake is thought to be the reason for the lake's freshness [40]. The basin experiences a bimodal rainfall pattern with a major peak in April-May and a minor peak in October-November coupled with recent climatic changes that lead to heavy rains and prolonged drought patterns [41, 42].

Lake Naivasha is a closed lake system vulnerable to changes in the catchment and climatic changes; since 2012 , the lake flooded parts of the terrestrial land around it increasing in size from $107.6 \mathrm{~km}^{2}$ to $168.87 \mathrm{~km}^{2}$ between 2010 and $2013[43,44]$. The lake is a Ramsar site, a wetland of international importance since 1995 [45] and a biodiversity hotspot with several species of birds and animals that depend on it. A number of economic activities rely on the lake's freshwater, the main one being irrigation for the thriving horticultural industry around the lake, which has doubled in the twenty-first century bringing with it a tenfold rise in population from additional workers and their dependents [30]. Other activities include cooling of the geothermal power plants, fishing and recreation for residents. Naivasha town is located on the northeastern side of the lake. The main lake experiences a number of ecological threats including high soil erosion from the escarpments in the east and nutrient runoff and pesticide from the farms $[26,35,46,47]$ and beaches that drain directly into the lake. Further from the lake basin in the head waters, farming of food crops is the main activity that threatens the ecology of the lake $[37,38,48]$.

\subsection{Sample collection, preparation and analysis}

A total of 41 surface lake sediments samples were collected from the main lake and Crescent island crater following a $5 \times 5 \mathrm{~km}$ grid sampling, determined using a handheld geographical position system in May 2016. Samples were obtained from a composite, mixing three subsamples collected at a site at $0-15 \mathrm{~cm}$ depth using an Ekman grab sampler. Totally, 250-500 g portion of this well-mixed composite was scooped and stored in PTFE polythene bags to avoid contamination. These were then stored in a cooler box during fieldwork and stored in the freezer at $-20^{\circ} \mathrm{C}$ at the Kenya Marine Fisheries Research Institute laboratory in Naivasha, during the field season. A subsample was later taken to the ICRAF soil Laboratory in Nairobi, Kenya, where they were air-dried in a temperature-controlled room at $60^{\circ} \mathrm{C}$, and then sieved through a 2-mm mesh screen to remove unwanted debris. A subsample was taken for texture analysis; the particle sizes were determined with a laser diffraction particle size analyzer (Coulter LS 100, particle size analyzer). The average of two readings was taken for each sample.

The remaining subsample was pulverized in a micronizing mill $(<53 \mu \mathrm{m})$, and elemental analyses were carried out using energy-dispersive $X$-ray fluorescence in a portable $X$-ray fluorescence ( $p X R F$ ) machine (Bruker III Tracer SD \#T3S2731; Bruker Kennewick, WA, USA and Tracer 5i) following the procedure by $[49,50]$. Analysis time was set for $1 \mathrm{~min}$. Two readings were made for each sample and the average recorded. Quality control assessment of the X-ray fluorescence ( $p X R F$ ) data included the use of soil-certified reference materials (CRMs): Katumani soil from Kenya with known concentration and a standard was run after 32 samples using a standardization plate (Aluminum 7075F) of known concentrations. For laser particle size analysis, Katumani soil and a commercial standard Nist with known concentrations were used.

\subsection{Estimation of contamination intensity}

\subsubsection{Spatial and statistical analysis}

To map the spatial distribution of heavy metal concentration and identify the pollution "hotspot" of each element, ordinary kriging was used for spatial interpolation within ArcGIS 10.2 platform [51].

Descriptive and multivariate statistical methods were performed to assess relationships of the heavy metals and the sampling sites under the SPSS software platform. We used the correlation matrix to identify correlation between sets of variables, and principal component analysis (PCA) was used to simplify and group the data to explain the variance and reveal relationships among the elements [23]. The suitability of data for PCA analysis was determined. In this study, the Kaiser-Meyer-Olkin and Bartlett's sphericity tests were 0.5 and 0.00 , respectively, indicating suitability and PCA was then performed. Factors with eigenvalues $>1$ were considered significant and the percent variance explained.

\subsubsection{Geoaccumulation index $\left(I_{\text {geo }}\right)$}

$I_{\text {geo }}$ is an environmental criteria introduced by Muller [52] used to assess the presence and intensity of anthropogenic pollution in the aquatic sediments. This empirical index compares a given concentration versus a value considered as geochemical background. It is classified into seven classes ranging from Class $0\left(I_{\text {geo }} \leq 0\right)$, which is practically uncontaminated; Class $1\left(I_{\text {geo }} 0-1\right)$ is 
uncontaminated to moderately contaminated; Class $2\left(I_{\text {geo }}\right.$ $1-2)$ is moderately contaminated; Class $3\left(I_{\text {geo }} 2-3\right)$ is moderately to heavily contaminated; Class $4\left(I_{\text {geo }} 3-4\right)$ is heavily contaminated; Class 5 ( $I_{\text {geo }} 4$ to 5 ) is heavily to extremely contaminated; Class $6\left(I_{\text {geo }}>5\right)$ is extremely contaminated.

It is determined using the formula:

$I_{\text {geo }}=\log _{2}\left(\frac{C_{n}}{1.5 B_{n}}\right)$

where $C_{n}$ is the measured concentration of a given heavy metal in the sediment, $\left(B_{n}\right)$ is the natural background value of a metal in the upper continental crust as reference material, and 1.5 is the background matrix correlation factor. The correlation factor is used to correct for possible variations in the background data due to lithogenic effects [52]. The background values used for each element are their upper continental crust values, i.e., $\mathrm{Co}(11.6 \mathrm{ppm}), \mathrm{Cr}$ (35 ppm), Cu (14.3 ppm), Mn (527 ppm), Pb (17 ppm), Zn (52 ppm) according to Wedepohl [53].

\subsubsection{Enrichment factor (EF)}

The second criterion used to estimate contamination intensity in sediments is the enrichment factor (EF). This is a ratio of the abundances of a potentially enriched element with respect to a reference element, used to determine the magnitude of anthropogenic metal pollution in the environment using a normalization element in order to moderate the variations produced by heterogeneous sediments [54].

$\mathrm{EF}$ is a useful environmental tool that can be used to determine whether the polluting metal in sediments is of anthropogenic or natural sources $[24,55]$. The EF calculation seeks to reduce the metal variability associated with variations in mud/sand ratios, and is used in plotting geochemical trends to reduce substantial variations in the grain ratios in large geographical areas [56]. Different elements ( $\mathrm{Al}, \mathrm{Fe}, \mathrm{K}, \mathrm{Li}, \mathrm{Sc}, \mathrm{Ga}, \mathrm{Rb}, \mathrm{Zr}$ and Ti) are used as normalizing elements [57]. Fe was used in this study as acceptable normalization element since its distribution is not related to other heavy metals and it has a relatively high natural concentration, with limited anthropogenic enrichment $[55,58]$.

$\mathrm{EF}$ is calculated as:

$\mathrm{EF}=\frac{\left[\frac{x}{\mathrm{Fe}}\right] \text { Samples }}{\left[\frac{x}{\mathrm{Fe}}\right] \text { Crust }}$

where $\left[\frac{x}{\mathrm{Fe}}\right]$ samples and $\left[\frac{x}{\mathrm{Fe}}\right]$ Crust refer to the ratios of mean concentrations of the target sample and Fe in the samples and in the continental crust, respectively.
EF values between 0.05 and 1.5 indicate that the metal is entirely from crustal materials or natural processes, whereas EF values higher than 1.5 suggest that the sources are more likely to be of anthropogenic origin [59].

\subsubsection{Potential ecological risk index (RI) and pollution load index (PLI)}

While EF is used to reflect the influence of human activities on the enrichment of a single heavy metal, it does not consider the bioavailability or combined effects of heavy metals [23]. Therefore, the potential ecological risk index (RI) developed by Hakanson [27] was used to assess the degree of heavy metal pollution in sediments, according to the toxicity of heavy metals and the response of the environment. It provides a quantitative value for the combined contamination risk to a particular ecological system $[27,60]$.

The sum of all risk factors per sampling site is then calculated in three steps; first the contamination factor $\left(C_{f}\right)$ of each metal element is determined which enables the calculation of potential ecological risk factor at each sampling site, and finally the sum of risk factors of each element at a point was estimated

$C_{\mathrm{f}}^{i}=C_{\mathrm{D}}^{i} / C_{\mathrm{B}}^{i}$

$E_{\mathrm{r}}^{i}=T_{\mathrm{r}}^{i} \times C_{\mathrm{f}}^{i}$

$\mathrm{RI}=\sum_{i=1}^{m} E_{\mathrm{r}}^{i}$

where $C_{f}$ is the contamination factor, $C_{D}$ is the concentration of heavy metals in sediments, and $C_{B}$ is the background value for the metal $(\mathrm{mg} / \mathrm{kg}) . E_{\mathrm{r}}^{i}$ is the potential ecological risk factor of a given metal, and it can be classified into five categories: low, $E_{\mathrm{r}}^{i}<40$; moderate, $40 \leq E_{\mathrm{r}}^{i}<80$; considerable, $80 \leq E_{\mathrm{r}}^{i}<160$; high, $160 \leq E_{\mathrm{r}}^{i}<320$; very high, $E_{\mathrm{r}}^{i} \geq 320$. $T_{\mathrm{r}}$ is the toxic response factor for the metal. $\mathrm{Rl}$ is the sum of risk factors for all metals at a sampling point [27]. $T_{r}$ values are: $\mathrm{Pb} \mathrm{5,} \mathrm{Cr} \mathrm{2,} \mathrm{Cu} \mathrm{5,} \mathrm{Zn} 1$ Mn 1 and Co 5 [27, $61,62]$. The evaluation index by [27] is based on eight pollutants ( $\mathrm{As}, \mathrm{Cd}, \mathrm{Cr}, \mathrm{Cu}, \mathrm{Hg}, \mathrm{Pb}, \mathrm{Zn}$ and PCBs) in sediments. This study analyzed only 5 of the elements, thus, because the grading criteria introduced by Hakanson [27] would underestimate the potential risk; a modified RI grading criteria as used by Li et al. [16] was adopted, whereby $\mathrm{RI}<105$ is low risk, $105 \leq \mathrm{RI}<210$ (moderate risk), $210 \leq \mathrm{RI}<420$ (considerable risk), $\mathrm{Rl} \geq 420$ (very high risk). Background values from Wedepohl [53] were used.

The overall pollution status in the sediments of Lake Naivasha is estimated using the pollution load index (PLI). 
A PLI value of $>1$ indicates a polluted area, and a $\mathrm{PLI}<1$ indicates no pollution. This was determined using the equation developed by Tomilnson et al. [21].

$\mathrm{PLI}=\left(\mathrm{CF}_{1} \times \mathrm{CF}_{2} \times \mathrm{CF}_{3} \times \cdots \mathrm{CF}_{n}\right)\left(\frac{1}{n}\right)$

where $\mathrm{CF}$ is the calculated contamination factor and $\mathrm{n}$ is the number of samples. CF is calculated in Eq. 3.

\section{Results and discussion}

\subsection{Sediment texture and heavy metal concentrations}

The sediments texture of Lake Naivasha is shown in Table 1 and supplementary 1 . Sand fraction varied from a maximum of $66.82 \%$ along the southeastern shore of the lake, while the maximum for silt and clay fractions is $47 \%$ and $68 \%$, respectively. Clays occur in the north around Malewa river inlet and central portions of the lake, while silt and sand are predominant in the south and southeastern shores of the lake. Similar studies by Tarras-Wahlberg et al. [35] concluded that the high clay at the Malewa river mouth is eroded from the farms in the upper catchment areas. Sediments brought in by the river runoff are mainly from the east and north of the catchment and very minimal in the west as the rivers do not get to the lake.

The concentrations of heavy metals in the sediments are presented in Table 1 and supplementary 1. The abundance of these metals was in the order of $\mathrm{Fe}>\mathrm{Mn}>\mathrm{Zn}$ $>\mathrm{Cu}>\mathrm{Cr}>\mathrm{Co}>\mathrm{Pb}$ with mean and ranges of concentrations as follows: Fe 53,655.60 (38,851.30-64,938.26) mg/ kg, Mn 1506.87 (1062.47-2653.43) mg/kg, Zn 231.94 (187.96-334.51) mg/kg, Cu 33.74 (23.05-46.93) mg/kg, Cr 27.44 (2.52-68.83) mg/kg, Co 24.04 (17.82-28.75) mg/kg and $\mathrm{Pb} 22.11$ (14.31-45.93) mg/kg. It can be noted that $\mathrm{Fe}$ and $\mathrm{Mn}$ concentrations are several orders of magnitude higher than the rest of the elements.

The region with the highest concentration of all heavy metals is south of the lake at Kamere beach (L65) and east at Karagita (L105), while the area with the least concentrations in the heavy metals is in the north side of Lake Naivasha. Elevated levels of $\mathrm{Mn}$ are found in the east at Crescent Island (112).

All the elements except $\mathrm{Cu}$ (background $45 \mathrm{mg} / \mathrm{kg}$ ) were higher than the shale background levels according to Wedepohl [53], indicating enrichment of the heavy metals in the lake sediments (Table 1). Upper continental crust values were used because published background values of Naivasha are not available.

The concentrations of $\mathrm{Cu}, \mathrm{Pb}, \mathrm{Fe}, \mathrm{Mn}$ and $\mathrm{Zn}$ from our study are higher than previously published results from ten sites in Lake Naivasha by Otachi, Körner [38]. However, compared to other freshwater lakes in the tropics considered highly polluted with industrial and agricultural pollutants, e.g., in Yilong, Poyang and Dongping lakes in China $[23,63,64]$, Zn concentrations are higher, while Pb concentrations were lower than these lakes.

The heavy metals $\mathrm{Co}, \mathrm{Cu}$ and $\mathrm{Fe}$ have a strong positive correlation with clay at $P<0.01, \mathrm{Co}(0.76), \mathrm{Cu}(0.41), \mathrm{Fe}$ (0.81) (Table 2), while no correlation exists between clay and $\mathrm{Mn}$ and $\mathrm{Zn}$. Sandy sediments are negatively correlated with $\mathrm{Co}, \mathrm{Cr}, \mathrm{Cu}, \mathrm{Fe}$ and $\mathrm{Pb}$ and weak positive correlations with $\mathrm{Mn}$ and $\mathrm{Zn}$. The high positive correlations for $\mathrm{Fe}, \mathrm{Co}$ and clay can be attributed to surface adsorption and ionic attraction [65]. And the strong association between Fe and Co could mean that the concentration of Co in Lake Naivasha sediments is controlled by Fe oxides and hydroxides. Cardoso, Boaventura [66] indicated that clays are the most important source of $\mathrm{Fe}$ and $\mathrm{Cu}$ in sediments.
Table 1 Summary statistics of heavy metal contents in surface sediments from Lake Naivasha background values and guideline values of freshwater sediment quality in $\mathrm{mg} / \mathrm{kg}$

\begin{tabular}{lcccccccccc}
\hline & Clay\% & Sand\% & Silt\% & Co & \multicolumn{1}{c}{$\mathrm{Cr}$} & $\mathrm{Cu}$ & $\mathrm{Fe}$ & $\mathrm{Mn}$ & $\mathrm{Pb}$ & $\mathrm{Zn}$ \\
\hline Mean & 32.89 & 30.27 & 36.84 & 24.04 & 27.44 & 33.74 & $53,655.60$ & 1506.87 & 22.11 & 231.94 \\
Min & 11.80 & 6.09 & 13.45 & 17.82 & 2.52 & 23.05 & $38,851.30$ & 1062.47 & 14.31 & 187.96 \\
Max & 58.51 & 66.85 & 47.47 & 28.75 & 68.83 & 46.93 & $64,948.26$ & 2658.43 & 45.93 & 334.51 \\
SD & 14.79 & 16.97 & 6.99 & 3.42 & 3.42 & 5.12 & $80,544.55$ & 332.30 & 5.54 & 23.42 \\
Shale $^{\mathrm{a}}$ & & & & 19 & 90 & 45 & 47,200 & 850 & 20 & 95 \\
TEL & & & & & 60 & 33.9 & & & 15 & 90 \\
PEL & & & & & 90 & 196.6 & & & 91.3 & 314.8 \\
\hline
\end{tabular}

The gaps are missing data

Min minimum, Max maximum, SD standard deviation; ${ }^{a}$ Background levels [53]; TEL threshold effect level, PEL probable effect level [28] 
Table 2 Spearman correlation matrix for heavy metals concentrations in surface sediments from Lake Naivasha

\begin{tabular}{lccllllllll}
\hline & Clay & Silt & Sand & Co & Cr & $\mathrm{Cu}$ & $\mathrm{Fe}$ & $\mathrm{Mn}$ & $\mathrm{Pb}$ & $\mathrm{Zn}$ \\
\hline Clay & 1 & & & & & & & & \\
Silt & -0.040 & 1 & & & & & & & \\
Sand & $-0.919^{* * *}$ & -0.259 & 1 & & & & & & & \\
$\mathrm{Co}$ & $0.756^{* *}$ & -0.056 & $-0.684^{* *}$ & 1 & & & & & & \\
$\mathrm{Cr}$ & 0.040 & -0.125 & -0.004 & 0.003 & 1 & & & & & \\
$\mathrm{Cu}$ & $0.406^{*}$ & 0.172 & $-0.429^{* *}$ & $0.427^{* *}$ & 0.201 & 1 & & & & \\
$\mathrm{Fe}$ & $0.808^{* *}$ & -0.022 & $-0.731^{* *}$ & $0.987^{* *}$ & -0.012 & $0.430^{* *}$ & 1 & & & \\
$\mathrm{Mn}$ & -0.269 & 0.052 & 0.242 & 0.026 & $0.378^{*}$ & 0.043 & -0.058 & 1 & & \\
$\mathrm{~Pb}$ & $0.376^{*}$ & 0.154 & $-0.389^{*}$ & $0.452^{* *}$ & 0.214 & $0.666^{* *}$ & $0.437^{* *}$ & 0.140 & 1 & \\
$\mathrm{Zn}$ & -0.040 & -0.114 & 0.108 & 0.035 & -0.114 & $0.404^{* *}$ & 0.021 & -0.117 & $0.554^{* *}$ & 1 \\
\hline
\end{tabular}

${ }^{*} P$ values are significant at $0.05 ;{ }^{* *}$ means $P$ values are significant at 0.01
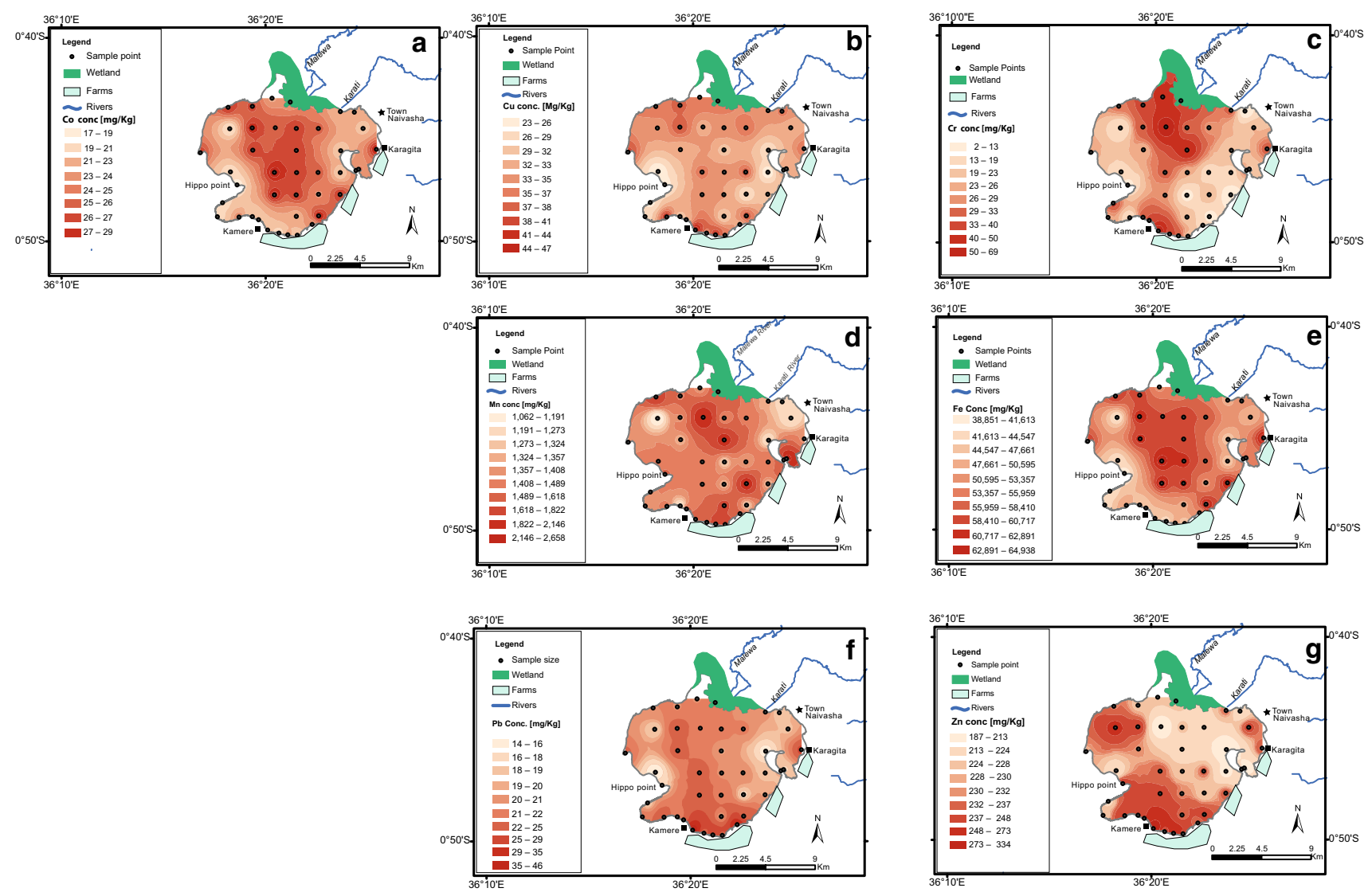

Fig. 2 Spatial distribution of heavy metals in Lake Naivasha

\subsection{Spatial distribution patterns of heavy metals in lake surface sediments}

Spatial distribution of heavy metals concentrations in surface sediments of Lake Naivasha is shown in Fig. 2. The maps created from spatial interpolation of each element illustrate the distinct zones of high or low metal element concentrations in the lake sediments. There is no uniform spatial pattern for the distribution of all the elements; however, Fe and Co have a similar spatial distribution both showing high levels in the central portion of the lake and low on the southwestern shoreline. The other five elements: $\mathrm{Cr}, \mathrm{Cu}, \mathrm{Pb}, \mathrm{Mn}$ and $\mathrm{Zn}$, are all enriched in the southern shore; additionally $\mathrm{Cr}$ and $\mathrm{Mn}$ are also enriched in the northern lake shore at the river mouths. High concentrations of $\mathrm{Zn}$ occur in three locations away from the river inlet occurring extensively in the northwest and southwest and in small zones on the northeastern side of the lake. 
The high concentration of $\mathrm{Cr}, \mathrm{Cu}, \mathrm{Pb}, \mathrm{Mn}$ and $\mathrm{Zn}$ in the southern shoreline of the lake could be linked to the human activities (removal of buffering plants such as papyrus and increased cultivation of the flower farms) in the area which have led to high erosion on land as evidenced by the dominance of sand and silty fractions and high magnetic susceptibilities found to be well above background [67]. Furthermore, the lake levels in the last decade have fluctuated, and at the time of sampling the southern shoreline had transgressed into former terrestrial land. Higher concentrations of $\mathrm{Cr}$ and $\mathrm{Mn}$ and $\mathrm{Pb}$ metals occur on the northern side, at Malewa and Karati river mouths. This can be attributed to the inflow from the rivers and inputs from the catchment into the lake.

Cobalt and iron are concentrated in the central parts of the lake which could be related to the source and also be due to relatively slow velocity of the water in this part which can promote desorption of suspended particles leading to metal deposition if the middle of the lake basin in Naivasha could be taken to represent background concentrations for the lake [67]. Similar conclusions were drawn for Qaroun Lake where part of the association of Fe and Co was most of a natural source [68]. Mn is concentrated in the lake sediments on the eastern side. The high concentration could be related to the bathymetry differences between the deep Crescent island crater and the shallow main lake that can lead to remobilization of $\mathrm{Mn}$ from deeper layers [57]. While in the northern side around the Malewa river mouth a high concentration of $\mathrm{Mn}$ is due to input from the rivers, a similar observation was made by Kamau et al. [36]. The spatial distribution mirrored parts of Poyang Lake in China. High concentrations of $\mathrm{Cr}$, $\mathrm{Cu}$, $\mathrm{Cd}, \mathrm{Pb}$ and $\mathrm{Zn}$ around the river mouth were attributed to contaminants and the deposition processes. In contrast, $\mathrm{Cr}$ and $\mathrm{Pb}$ were highly concentrated in the middle section of the lake [64]. Similarly in the Mwanza Gulf, in Lake Victoria, Tanzania, high levels of $\mathrm{Pb}$ and $\mathrm{Zn}$ were recorded around the shore lines [69].

\subsection{Source identification and Heavy metal contamination}

\subsubsection{Geoaccumulation Index $\left(I_{\text {geo }}\right)$}

The mean $I_{\text {geo }}$ values of Lake Naivasha sediments are shown in Table 3 and Fig. 3 . The mean $I_{\text {geo }}$ values for the elements are: $\mathrm{Co}(0.4), \mathrm{Cr}(-1.17), \mathrm{Cu}(0.6), \mathrm{Mn}(0.86), \mathrm{Pb}$ $(-0.24)$ and $\mathrm{Zn}(1.56)$. Thus, it can be arranged in the following increasing order $\mathrm{Cr}<\mathrm{Pb}<\mathrm{Co}<\mathrm{Cu}<\mathrm{Mn}<\mathrm{Zn}$. This range of $I_{\text {geo }}$ values falls in three classes (class 0 , class 1 and class 2) indicating unpolluted to moderate pollution in sediments. $I_{\text {geo }}$ values are less than 1 for 3 elements: $\mathrm{Cr}$ (range -3.32 to 0.39 ) Co (range -0.01 to 0.68 ) and $\mathrm{Pb}$
Table 3 Mean and range of EF and $l_{\text {geo }}$ of heavy metals in sediments in Lake Naivasha

\begin{tabular}{llllll}
\hline & \multicolumn{2}{l}{$l_{\text {geo }}$} & & & EF \\
\cline { 2 - 3 } \cline { 5 - 5 } & Mean & Range & & Mean & Range \\
\hline $\mathrm{Co}$ & 0.4 & 0.01 to 0.68 & & 1.20 & 1.15 to 1.42 \\
$\mathrm{Cr}$ & $<0$ & -3.32 to 0.39 & & 0.45 & 0.03 to 1.30 \\
$\mathrm{Cu}$ & 0.6 & -2.32 to 1.16 & & 1.38 & 1.06 to 2.27 \\
$\mathrm{Mn}$ & 0.9 & 0.39 to 1.76 & & 1.68 & 1.15 to 2.90 \\
$\mathrm{~Pb}$ & $<1$ & -0.83 to 0.85 & & 0.76 & 0.58 to 1.87 \\
$\mathrm{Zn}$ & 1.6 & 1.10 to 2.10 & & 2.62 & 1.91 to 4.45 \\
\hline
\end{tabular}

(range -0.83 to 0.85 ), showing that the lake sediments are uncontaminated to moderately contaminated in these elements. Sediments are unpolluted in $\mathrm{Pb}$ in $88 \%$ of the lake, while $I_{\text {geo }}$ for $\mathrm{Cu}, \mathrm{Mn}$ and $\mathrm{Zn}$ ranging between -2.32 to $1.16,0.39$ to 1.76 and 1.1 to 2.1 , respectively, falls into class 1 and class 2 showing from uncontaminated to moderately contaminated sediments. While these classes are low, sections of the lake are of concern as they are moderately contaminated in certain sites, for example $22 \%$ of $\mathrm{Mn}$ are in class 1 . The higher $I_{\text {geo }}$ values for $\mathrm{Mn}$ are found in two locations, i.e., in the southeast at Crescent Island, further away from river inflow and in the north at Malewa river mouth (1.52) the largest river in the catchment with farming activities. $I_{\text {geo }}$ values for $\mathrm{Zn}(1.1-2.1)$ are generally higher than all the elements indicating moderate levels of pollution in the lake sediments. While the point with the highest $I_{\text {geo }}$ in $\mathrm{Zn} \mathrm{(2.1)} \mathrm{is} \mathrm{in} \mathrm{the} \mathrm{south} \mathrm{in} \mathrm{Kamere} \mathrm{beach,} \mathrm{the}$ lowest $I_{\text {geo }}$ values for $\mathrm{Zn} \mathrm{(1.27)} \mathrm{are} \mathrm{found} \mathrm{at} \mathrm{Malewa} \mathrm{river}$ mouth. Compared to other studies, the $\mathrm{Zn} \mathrm{I}_{\text {geo }}$ values were lower than upper Tigris River sediments which was polluted by a copper mine [70] but higher than Lake Nasser sediments [71].

\subsubsection{Enrichment factor}

$\mathrm{EF}$ of the elements $\mathrm{Cr}, \mathrm{Co}, \mathrm{Cu}, \mathrm{Pb}, \mathrm{Zn}, \mathrm{Mn}$ ranges as follows $<0-1.3,1.15-1.42,1.06-2.27,1.06-2.27,1.91-4.45$ and 1.15-2.9, respectively, as shown in Table 3. The mean $\mathrm{EF}$ values of the elements can be arranged in the following decreasing order: $\mathrm{Zn}>\mathrm{Mn}>\mathrm{Cu}>\mathrm{Co}>\mathrm{Pb}>\mathrm{Cr}$ (Fig. 4, Table 3), which is similar to the order of the $I_{\text {geo }}$ values. EF helps to assess anthropogenic contributions in lake sediments; values above 1.5 indicate that the metal elements are of anthropogenic origin, while lower values indicate natural enrichment [59]. The lowest $\mathrm{EF}$ values for $\mathrm{Cr}$ and $\mathrm{Co}$, which are below 1.5, indicate a lithogenic origin, while $\mathrm{Cu}$, $\mathrm{Pb}$ and $\mathrm{Mn}$ have intermediate $\mathrm{EF}$ values ranging from $<1.5$ to $>1.5$ showing both natural and anthropogenic enrichment. Totally, $63 \%$ of the sites indicate anthropogenic 
Fig. 3 Box plots showing $I_{\text {geo }}$ values of heavy metals in Lake Naivasha

Fig. 4 Box plot showing EF values of elements in Lake Naivasha
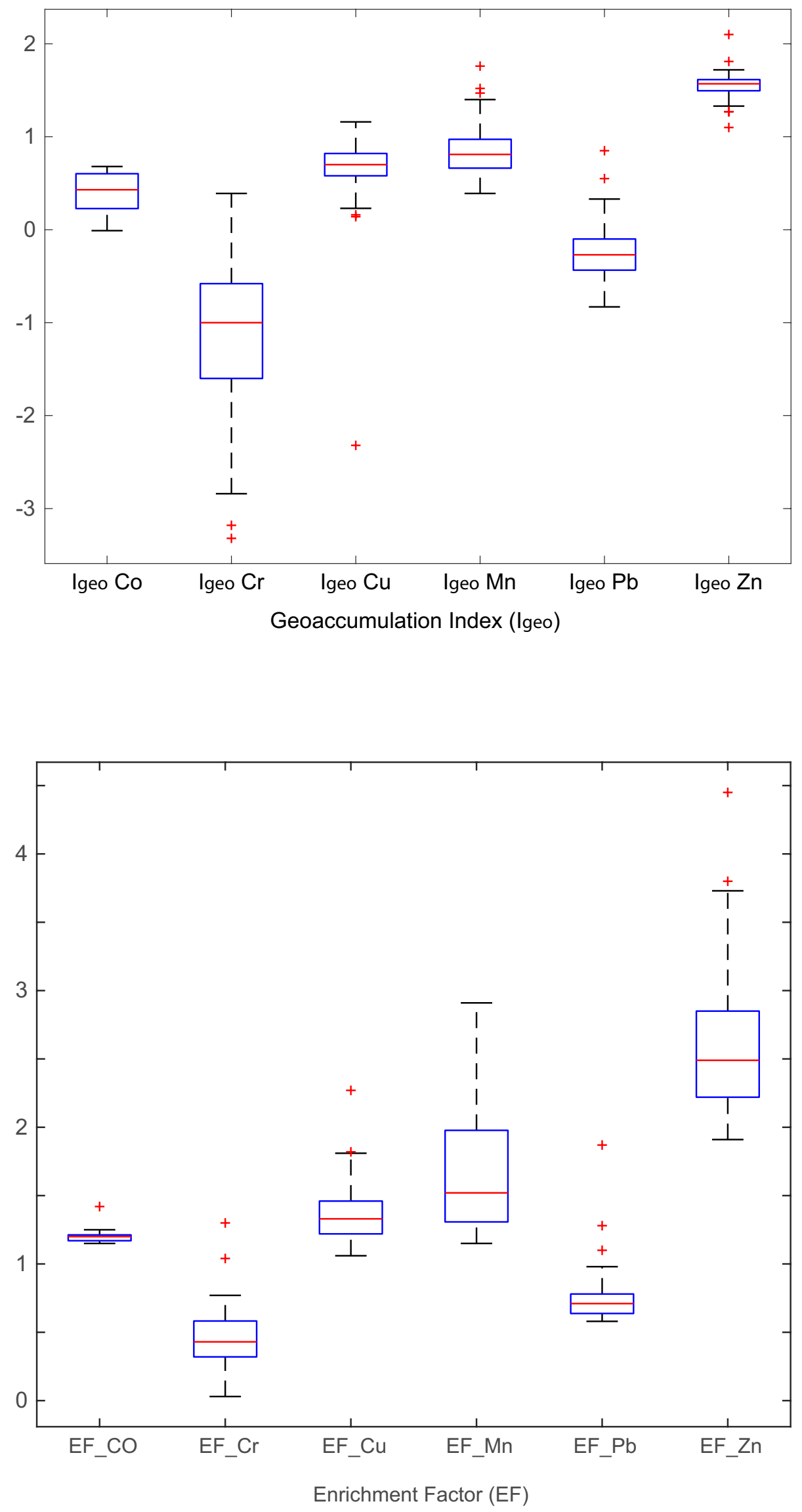
enrichment for $\mathrm{Mn}$ in the lake. $\mathrm{Zn}$ has the highest $\mathrm{EF}$ values in the lake sediments (1.91-4.45, Fig. 4) and also has high $I_{\text {geo }}$ values showing anthropogenic enrichment in all the sites. The maximum EF values of $\mathrm{Cu}(2.27), \mathrm{Pb}(1.87)$ and $\mathrm{Zn}$ (4.45) occur in the same site on the southern shoreline of the lake along Kamere beach, while the area with the lowest EF was nearer to the central regions of the lake

The higher $E F$ for $\mathrm{Zn}$ found in the northeast around river mouths and sewage point and the public beach area on southern side of the lake could be linked with the effluents from sewage and boating activities occurring in those regions. Enrichment of $\mathrm{Zn}$ and $\mathrm{Cu}$ around river mouths in Kaohsuing harbor Taiwan [72] and along the shores of Thermaikos gulf compared to the deeper sediments [73] was attributed to catchment activities such as wash off from the land-based activities and high amount of discharge from nearby industrial plant and shores. Additionally, a high EF for Zn in Rawal Lake in Egypt was attributed to domestic agricultural runoff [58], while in Pulicat Lake in India $\mathrm{Zn}$ was contributed by domestic and sewage wastes [74]. In contrast, the minimum EF and $I_{\text {geo }}$ values for $\mathrm{Zn}$ were along Malewa River mouth, and thus agricultural activities along Malewa are not contributing to $\mathrm{Zn}$ pollution in the lake. The anthropogenic sources of $\mathrm{Zn}$ in the sediments can be attributed to intense boating activities along the beaches. The expansion of the lake area to the south and northeast due to flooding [43] incorporated more heavy metals along these shores. Previous studies have shown that Lake Naivasha sediments are enriched with $\mathrm{Mn}$ whose source is both natural and anthropogenic $[36,75]$.

\subsubsection{Multivariate statistical analysis}

Multivariate statistical analyses were performed to deduce which metals are from similar sources in the lake sediments. PCA reduced the number of the variables to three principal components which explained about $85 \%$ of the data variance, as shown in Table 4. PC1 explained $38 \%$ of the total variance and is dominated by $\mathrm{Zn}, \mathrm{Pb}$ and $\mathrm{Cu}$, while PC2 explained $18 \%$ and is dominated by Fe and $\mathrm{Co}$ and $\mathrm{PC} 3$ is primarily dominated by $\mathrm{Mn}$ and $\mathrm{Cr}$ and accounts for $19 \%$ of the total variance. Additionally, $\mathrm{Zn}$, $\mathrm{Pb}$ and $\mathrm{Cu}$ are positively correlated, implying similar origin; their mean enrichment factor values are above 1.5 which point to an anthropogenic source. In Poyang Lake, similar results were reported of correlations between $\mathrm{Zn}, \mathrm{Cu}, \mathrm{Pb}$ and attributed to anthropogenic origins [64]. Fe and Co are also positively correlated, their $I_{\text {geo }}$ values point to a lithogenic origin, and $\mathrm{Fe}$ is a major component of rock forming minerals in the area. $\mathrm{Mn}$ and $\mathrm{Cr}$ have no correlation though their $\mathrm{EF}$ values point to an anthropogenic origin. In general, the inference on the sources deduced from PCA
Table 4 Principal component analysis (PCA) for elements in the surface sediments of Lake Naivasha

\begin{tabular}{lccc}
\hline Variables & \multicolumn{3}{l}{ Principal loading factors } \\
\cline { 2 - 4 } & PC1 & PC2 & PC3 \\
\hline $\mathrm{Co}$ & 0.059 & 0.988 & 0.062 \\
$\mathrm{Cr}$ & 0.318 & -0.048 & 0.796 \\
$\mathrm{Cu}$ & 0.789 & 0.409 & 0.071 \\
$\mathrm{Fe}$ & 0.06 & 0.991 & 0.012 \\
$\mathrm{Mn}$ & -0.216 & 0.112 & 0.837 \\
$\mathrm{~Pb}$ & 0.896 & 0.09 & 0.148 \\
$\mathrm{Zn}$ & 0.907 & -0.178 & -0.137 \\
Eigenvalues & 2.67 & 1.96 & 1.33 \\
\% Variance & 38 & 28 & 19 \\
Cumulative variance & 38 & 66 & 85 \\
\hline
\end{tabular}

$P C 1$ first principal component, $P C 2$ second principal component, $P C 3$ third principal component

analysis is similar to the EF for all elements except in the case of $\mathrm{Cu}$ which had a range from natural and anthropogenic enrichment; therefore, we suppose that because the concentrations of $\mathrm{Cu}$ are generally low, our observation agrees with [23] conclusion that PCA is less effective in differentiating contamination sources when the pollution levels of a given metal are low.

\subsubsection{Analysis of the potential ecological risk of heavy metals in sediments}

The potential ecological risk and the sum of all risk factors of heavy metals in the sediments of Lake Naivasha are shown in Table 5. Cu has the highest potential ecological risk $E_{r}^{i}$, while $\mathrm{Cr}$ has the least value at 11.80 and 1.55 , respectively. The mean toxicity can be ranked in the decreasing order: $\mathrm{Cu}>\mathrm{Fe}>\mathrm{Co}>\mathrm{Zn}>\mathrm{Mn}>\mathrm{Cr}$. However, all elements show low ecological risks in Lake Naivasha because the $E_{\mathrm{r}}^{i}$ value for each element studied is $<40$.

Sediment Quality Guidelines (SQGs) are very important for protection of benthic organisms in freshwater ecosystems and can be used to assess sediment ecosystem health. Of the elements $\mathrm{Pb}, \mathrm{Zn}, \mathrm{Cr}$ and $\mathrm{Cu}, 95 \%$ of $\mathrm{Pb}$ are below TEL, $\mathrm{Cr}, 87.8 \%, \mathrm{Cu}, 58.54 \%$ and $\mathrm{Zn}=0 \%$ (Table 6). Only $5 \%$ for $\mathrm{Pb}$ are between TEL and PEL, $98 \%$ of $\mathrm{Zn}$ are between TEL and PEL, $12.19 \%$ of $\mathrm{Cr}$ are between TEL and PEL and $36 \%$ the Cu are between TEL and PEL; only Zn has $2 \%$ above $P E L$, while the others are zero. In $98 \%$ of sites sampled, $\mathrm{Zn}$ levels are above the threshold effect level (TEL) and lower than the probable effect levels (PEL) and only $2 \%$ are above the PEL. The TEL is intended to identify contaminant concentrations below which harmful effects on benthic organisms are not expected, while the PEL identifies contaminant concentrations above which 
Table 5 Er, RI and PLI values of heavy metals in sediments from Lake Naivasha

\begin{tabular}{|c|c|c|c|c|c|c|c|c|c|}
\hline Sample & ErCo & $\mathrm{ErCr}$ & $\mathrm{ErCu}$ & ErFe & ErMn & $\mathrm{ErPb}$ & $\mathrm{Zn}$ & $\mathrm{RI}$ & PLI \\
\hline $54 \mathrm{~L}$ & 10.59 & 0.60 & 14.43 & 10.5 & 2.73 & 7.80 & 4.82 & 51.4 & 1.8 \\
\hline $56 \mathrm{~L}$ & 8.40 & 2.06 & 8.78 & 8.07 & 2.65 & 5.42 & 4.24 & 39.6 & 1.7 \\
\hline $57 \mathrm{~L}$ & 7.68 & 0.50 & 8.62 & 7.55 & 2.88 & 5.14 & 4.69 & 37.1 & 1.4 \\
\hline $59 \mathrm{~L}$ & 8.33 & 1.02 & 8.21 & 8.13 & 2.76 & 4.21 & 4.07 & 36.7 & 1.5 \\
\hline $60 \mathrm{~L}$ & 11.70 & 1.46 & 13.70 & 11.72 & 2.67 & 6.89 & 4.42 & 52.5 & 2.0 \\
\hline $61 \mathrm{~L}$ & 7.88 & 0.50 & 11.59 & 7.80 & 2.02 & 5.29 & 4.94 & 40.0 & 1.4 \\
\hline $62 \mathrm{~L}$ & 11.94 & 1.63 & 12.83 & 11.80 & 3.45 & 6.22 & 4.47 & 52.3 & 2.1 \\
\hline $63 \mathrm{~L}$ & 8.36 & 1.84 & 10.48 & 8.31 & 2.07 & 5.18 & 4.41 & 40.6 & 1.7 \\
\hline $64 \mathrm{~L}$ & 9.46 & 2.01 & 10.91 & 9.26 & 2.93 & 7.01 & 4.77 & 46.3 & 1.9 \\
\hline $65 \mathrm{~L}$ & 8.86 & 3.77 & 16.41 & 8.68 & 2.86 & 13.51 & 6.43 & 60.5 & 2.5 \\
\hline $66 \mathrm{~L}$ & 8.15 & 2.08 & 12.25 & 8.08 & 2.96 & 6.38 & 4.45 & 44.3 & 1.9 \\
\hline $67 \mathrm{~L}$ & 9.93 & 1.85 & 14.61 & 9.68 & 3.35 & 8.70 & 5.27 & 53.3 & 2. \\
\hline $68 \mathrm{~L}$ & 8.62 & 1.22 & 12.60 & 8.71 & 3.34 & 7.13 & 4.71 & 46.3 & 1.8 \\
\hline $69 \mathrm{~L}$ & 9.57 & 1.19 & 9.86 & 9.61 & 3.20 & 5.70 & 4.47 & 43.6 & 1.7 \\
\hline $70 \mathrm{~L}$ & 12.29 & 0.53 & 13.31 & 12.56 & 2.40 & 7.09 & 4.68 & 52.8 & 1.7 \\
\hline $71 \mathrm{~L}$ & 10.20 & 1.00 & 11.39 & 10.26 & 2.85 & 10.94 & 4.45 & 51.0 & 1.9 \\
\hline $72 \mathrm{~L}$ & 10.44 & 1.51 & 8.95 & 10.14 & 3.94 & 5.14 & 4.29 & 44.4 & 1.9 \\
\hline $73 \mathrm{~L}$ & 11.98 & 0.14 & 11.00 & 12.28 & 2.48 & 5.91 & 4.55 & 48.3 & 1.4 \\
\hline $74 \mathrm{~L}$ & 8.50 & 0.98 & 8.06 & 8.54 & 2.59 & 5.50 & 3.98 & 38.2 & 1.6 \\
\hline $75 \mathrm{~L}$ & 11.32 & 0.91 & 13.29 & 11.41 & 2.48 & 6.21 & 4.54 & 50.2 & 1.8 \\
\hline $77 \mathrm{~L}$ & 9.00 & 0.43 & 11.71 & 12.06 & 2.48 & 6.37 & 4.43 & 49.4 & 1.6 \\
\hline $78 \mathrm{~L}$ & 11.77 & 1.32 & 11.18 & 12.01 & 2.50 & 7.07 & 4.44 & 50.3 & 1.9 \\
\hline $81 \mathrm{~L}$ & 12.13 & 1.86 & 13.55 & 12.28 & 2.63 & 7.44 & 4.72 & 54.6 & 2.2 \\
\hline $82 \mathrm{~L}$ & 11.54 & 2.00 & 12.93 & 11.62 & 2.82 & 6.18 & 4.36 & 51.4 & 2.1 \\
\hline $83 \mathrm{~L}$ & 9.88 & 2.48 & 12.70 & 10.17 & 2.57 & 6.19 & 4.33 & 48.3 & 2.0 \\
\hline $94 \mathrm{~L}$ & 10.14 & 2.15 & 12.71 & 10.41 & 2.93 & 6.41 & 4.40 & 49.2 & 2.1 \\
\hline $95 \mathrm{~L}$ & 11.33 & 3.93 & 11.26 & 11.34 & 4.30 & 6.45 & 3.61 & 52.2 & 2.3 \\
\hline $96 \mathrm{~L}$ & 11.85 & 1.70 & 12.00 & 11.83 & 2.67 & 6.39 & 4.37 & 50.8 & 2.0 \\
\hline $97 \mathrm{~L}$ & 11.23 & 1.49 & 12.94 & 11.51 & 2.82 & 6.36 & 4.17 & 50.5 & 2.0 \\
\hline $98 \mathrm{~L}$ & 11.69 & 3.01 & 10.68 & 11.73 & 3.82 & 5.86 & 4.15 & 50.9 & 2.2 \\
\hline $100 \mathrm{~L}$ & 12.39 & 1.81 & 12.72 & 12.55 & 2.71 & 7.60 & 4.54 & 54.3 & 2.2 \\
\hline $102 \mathrm{~L}$ & 11.87 & 1.37 & 12.17 & 12.04 & 2.41 & 6.12 & 4.32 & 50.3 & 1.9 \\
\hline $103 \mathrm{~L}$ & 12.38 & 1.49 & 12.11 & 12.61 & 2.74 & 6.81 & 4.58 & 52.7 & 2.1 \\
\hline $104 \mathrm{~L}$ & 12.19 & 1.83 & 12.89 & 12.53 & 2.63 & 7.78 & 4.59 & 54.4 & 2.2 \\
\hline $105 \mathrm{~L}$ & 9.17 & 1.36 & 11.27 & 9.37 & 2.20 & 5.67 & 4.64 & 43.7 & 1.8 \\
\hline $106 \mathrm{~L}$ & 10.19 & 1.99 & 11.95 & 10.56 & 2.25 & 6.05 & 4.45 & 47.4 & 1.9 \\
\hline 107L & 9.57 & 0.32 & 12.48 & 9.95 & 2.28 & 5.53 & 4.13 & 44.3 & 1.4 \\
\hline $108 \mathrm{~L}$ & 9.41 & 1.82 & 11.79 & 9.69 & 2.53 & 6.07 & 4.50 & 45.8 & 1.9 \\
\hline $109 \mathrm{~L}$ & 8.67 & 1.26 & 9.36 & 8.74 & 2.21 & 4.50 & 3.62 & 38.3 & 1.5 \\
\hline $110 \mathrm{~L}$ & 10.73 & 0.89 & 11.03 & 10.39 & 5.04 & 5.13 & 3.78 & 47.0 & 1.0 \\
\hline $112 \mathrm{~L}$ & 10.74 & 2.26 & 13.05 & 10.88 & 4.12 & 5.27 & 4.11 & 50.4 & 2.1 \\
\hline Mean & 10.29 & 1.55 & 11.80 & 10.42 & 2.86 & 6.50 & 4.46 & & \\
\hline
\end{tabular}

harmful effects on benthic organisms are expected to occur frequently [28]. Thus, $\mathrm{Zn}$ is the only element whose levels in Lake Naivasha have the potential to cause adverse effects to biota.

Compared to the Sedimentary Quality Guidelines, the mean for $\mathrm{Cu}$ is almost similar to the threshold effect level (TEL-below which no adverse effect can occur); however, in $37 \%$ of the sites the levels are between the threshold effect level and probable effect level (above which adverse effects on biota is expected), as shown in Table 6, indicating that the levels of Cu in Lake Naivasha can occasionally cause adverse effects. There is low concentration of $\mathrm{Cu}$ in the sediments, and we speculate that there could be more 
Table 6 Comparison of TEL and PEL values and heavy metal concentrations in percentage in Lake Naivasha Source: Macdonald et al. [28]

\begin{tabular}{lcccc}
\hline & $\mathrm{Pb}(\%)$ & $\mathrm{Zn}(\%)$ & $\mathrm{Cr}(\%)$ & $\mathrm{Cu}(\%)$ \\
\hline$<$ TEL & 95 & 0 & 87.8 & 58.54 \\
$>$ TEL $<$ PEL & 5 & 98 & 12.19 & 36.58 \\
$>$ PEL & 0 & 2 & 0 & 0 \\
\hline
\end{tabular}

Threshold effect level (TEL), above which adverse effects on biota occur rarely, probable effect levels (PEL) above which adverse effects on biota occur frequently

of $\mathrm{Cu}$ in the labile fractions (water and suspended materials) and not adsorbed in sediments.

The potential ecological risk index of the sediments in Lake Naivasha ranges from 36.73 to 60.51 , depicting lowto-moderate ecological risk. About half of the lake $(49 \%)$ has moderate ecological risk $(\mathrm{RI}>50)$. This is the entire central region of the lake and extends $\mathrm{N}-\mathrm{S}$, while the other half, the east and western portions of the lake, have low ecological risk.

The overall pollution status of Lake Naivasha sediments determined using the Pollution Load Index (PLI) ranges between 1.42 and 2.58 and also shows moderate-to-considerable pollution levels (Table 5). Moreover, some sites that showed a high ecological risk also have high pollution load indices such as Kamere beach. Tarambeta (2.10), Malewa river mouth (2.32) and Crescent island (2.13); the higher values indicate considerable pollution owing to the impact of anthropogenic activities such as agriculture and beach activities in these areas.

\subsection{Implications of lake management}

From the results, Lake Naivasha classifies as unpolluted to moderately polluted; this is surprising considering the increase in commercial farming and urban development in the catchment area. However, compared to other lakes globally, lakes in areas where mining and industries occur have higher heavy metals in the sediments $[24,64,76]$. The source of heavy metals in the lake is mostly from farming, urban effluents and beach activities. However, increase in the heavy metals can alter the phytoplankton community, and cause a decrease in aquatic species richness [77].

One other factor that could have contributed to increasing the heavy metals load along the northeastern and southern shores is the fact that Lake Naivasha has been flooded for the last 7 years, rapidly increasing in area by about $58 \%$ between 2010 and $2013[43,78]$ and is currently $158 \mathrm{Km}^{2}$. The flooded areas are the low lying riparian land which were farmlands, public beach and sewage points

\section{Conclusions}

The grid point sampling and spatial analysis of sediment characteristics were useful to establish the sediment status in all lake zones (sub-habitats) and developed baselines. Most of the heavy metals are of anthropogenic origin $\mathrm{Zn}, \mathrm{Cu}, \mathrm{Pb}, \mathrm{Mn}$ and $\mathrm{Cr}$, while $\mathrm{Fe}$ and $\mathrm{Co}$ are of lithogenic origin. $\mathrm{Fe}$ is the most abundant heavy metal element in the lake. Totally, $49 \%$ of the sediments are categorized as "unpolluted to moderately polluted" for all heavy metals, except $Z n$ metal that is "moderately to strongly polluted," hence, $\mathrm{Zn}$ threats to aquatic ecosystem should not be ignored. Though the heavy metals pose a low ecological risk $(\mathrm{RI}<50)$ in the lake, proper management plans need to be put in place; and priority areas for remediation interventions are the central portion of the lake areas, and the south and eastern shoreline have a high level of pollution (high PLI and RI values).

Future studies in the lake should be carried out to investigate bioaccumulation of $\mathrm{Zn}$ levels in macro-invertebrates and in addition identification of its anthropogenic sources to help with remediation and control plans. Similar studies are needed for other rift lakes experiencing pressure due to increase in commercial faming and industrialization.

Acknowledgements The research was made possible by funds from the Volkswagen Foundation to L.O. Project 89369. We would like to thank the Kenya Marine Fisheries Staff for their support, specifically Tom Nyoro and Mark Asiago. We are indebted to James Mungai and John Nga'nga' who oversaw the sampling logistics. The study is carried out under NACOSTI permit number NACOSTI/P/16/11924/11448. We thank the anonymous reviewers whose comments improved the manuscript.

\section{Compliance with ethical standards}

Conflict of interest The authors declare that they have no conflict of interest.

Open Access This article is licensed under a Creative Commons Attribution 4.0 International License, which permits use, sharing, adaptation, distribution and reproduction in any medium or format, as long as you give appropriate credit to the original author(s) and the source, provide a link to the Creative Commons licence, and indicate if changes were made. The images or other third party material in this article are included in the article's Creative Commons licence, unless indicated otherwise in a credit line to the material. If material is not included in the article's Creative Commons licence and your intended use is not permitted by statutory regulation or exceeds the permitted use, you will need to obtain permission directly from the copyright holder. To view a copy of this licence, visit http://creativecommons .org/licenses/by/4.0/. 


\section{References}

1. MEA. Ecosystems and Human Well-being: Synthesis. Washington, DC; 2005

2. Michelutti N, Wolfe AP, Cooke CA, Hobbs WO, Vuille M, Smol JP (2015) Climate change forces new ecological states in tropical Andean lakes. PLoS ONE 10(2):e0115338

3. Spears BM, Carvalho L, Futter MN, May L, Thackeray SJ, Adrian $R$ et al (2016) Ecological instability in lakes: a predictable condition?. ACS Publications, Washington

4. Keppeler FW, de Souza AC, Hallwass G, Begossi A, de Almeida MC, Isaac VJ et al (2018) Ecological influences of human population size and distance to urban centres on fish communities in tropical lakes. Aquat Conserv Mar Freshw Ecosyst 28(5):1030-1043

5. Pradit S, Pattarathomrong MS, Panutrakul S (2013) Arsenic cadmium and lead concentrations in sediment and biota from Songkhla Lake: a review. Procedia-Soc Behav Sci 91:573-580

6. Bryan G, Langston W (1992) Bioavailability, accumulation and effects of heavy metals in sediments with special reference to United Kingdom estuaries: a review. Environ Pollut 76(2):89-131

7. De Grave S, Smith KG, Adeler NA, Allen DJ, Alvarez F, Anker A et al (2015) Dead shrimp blues: a global assessment of extinction risk in freshwater shrimps (Crustacea: Decapoda: Caridea). PLoS ONE 10(3):e0120198

8. Torres Z, Mora MA, Taylor RJ, Alvarez-Bernal D (2016) Tracking metal pollution in Lake Chapala: concentrations in water, sediments, and fish. Bull Environ Contam Toxicol 97(3):418-424

9. Zhang A, Wang L, Zhao S, Yang X, Zhao Q, Zhang X et al (2017) Heavy metals in seawater and sediments from the northern Liaodong Bay of China: levels, distribution and potential risks. Reg Stud Mar Sci 11:32-42

10. Calmano W, Hong J, Förstner U (1993) Binding and mobilization of heavy metals in contaminated sediments affected by $\mathrm{pH}$ and redox potential. Water Sci Technol 28(8-9):223-235

11. Eggleton J, Thomas KV (2004) A review of factors affecting the release and bioavailability of contaminants during sediment disturbance events. Environ Int 30(7):973-980

12. Chen W, Tan S, Tay J (1996) Distribution, fractional composition and release of sediment-bound heavy metals in tropical reservoirs. Water Air Soil Pollut 92(3-4):273-287

13. Linnik PM, Zubenko IB (2000) Role of bottom sediments in the secondary pollution of aquatic environments by heavy-metal compounds. Lakes Reserv Res Manag 5(1):11-21

14. Ho HH, Swennen R, Cappuyns V, Vassilieva E, Van Gerven T, Van Tran T (2012) Potential release of selected trace elements (As, $\mathrm{Cd}, \mathrm{Cu}, \mathrm{Mn}, \mathrm{Pb}$ and $\mathrm{Zn}$ ) from sediments in Cam River-mouth (Vietnam) under influence of $\mathrm{pH}$ and oxidation. Sci Total Environ 435:487-498

15. Fu J, Zhao C, Luo Y, Liu C, Kyzas GZ, Luo Y et al (2014) Heavy metals in surface sediments of the Jialu River, China: their relations to environmental factors. J Hazard Mater 270:102-109

16. Li F, Huang J, Zeng G, Yuan X, Li X, Liang J et al (2013) Spatial risk assessment and sources identification of heavy metals in surface sediments from the Dongting Lake, Middle China. J Geochem Explor 132:75-83

17. Suresh $G$, Sutharsan $P$, Ramasamy V, Venkatachalapathy $R$ (2012) Assessment of spatial distribution and potential ecological risk of the heavy metals in relation to granulometric contents of Veeranam lake sediments, India. Ecotoxicol Environ Saf 84:117-124

18. Barbosa J, Cabral T, Ferreira D, Agnez-Lima L, De Medeiros SB (2010) Genotoxicity assessment in aquatic environment impacted by the presence of heavy metals. Ecotoxicol Environ Saf 73(3):320-325
19. Weber P, Behr ER, Knorr CDL, Vendruscolo DS, Flores EM, Dressler VL et al (2013) Metals in the water, sediment, and tissues of two fish species from different trophic levels in a subtropical Brazilian river. Microchem J 106:61-66

20. Tang W, Zhao Y, Wang C, Shan B, Cui J (2013) Heavy metal contamination of overlying waters and bed sediments of Haihe Basin in China. Ecotoxicol Environ Saf 98:317-323

21. Tomlinson D, Wilson J, Harris C, Jeffrey D (1980) Problems in the assessment of heavy-metal levels in estuaries and the formation of a pollution index. Helgoländer meeresuntersuchungen 33(1):566

22. Abrahim G, Parker R (2008) Assessment of heavy metal enrichment factors and the degree of contamination in marine sediments from Tamaki Estuary, Auckland, New Zealand. Environ Monit Assess 136(1-3):227-238

23. Wang Y, Yang L, Kong L, Liu E, Wang L, Zhu J (2015) Spatial distribution, ecological risk assessment and source identification for heavy metals in surface sediments from Dongping Lake, Shandong, East China. CATENA 125:200-205

24. El-Amier YA, Elnaggar AA, El-Alfy MA (2017) Evaluation and mapping spatial distribution of bottom sediment heavy metal contamination in Burullus Lake, Egypt. Egypt J Basic Appl Sci 4(1):55-66

25. Men C, Liu R, Xu F, Wang Q, Guo L, Shen Z (2018) Pollution characteristics, risk assessment, and source apportionment of heavy metals in road dust in Beijing, China. Sci Total Environ 612:138-147

26. Abbasi Y, Mannaerts CM (2018) Evaluating organochlorine pesticide residues in the aquatic environment of the Lake Naivasha River basin using passive sampling techniques. Environ Monit Assess 190(6):349

27. Hakanson $L$ (1980) An ecological risk index for aquatic pollution control. A sedimentological approach. Water Res 14(8):975-1001

28. MacDonald DD, Ingersoll CG, Berger TA (2000) Development and evaluation of consensus-based sediment quality guidelines for freshwater ecosystems. Arch Environ Contam Toxicol 39(1):20-31

29. Kitaka N, Harper DM, Mavuti KM (2002) Phosphorus inputs to Lake Naivasha, Kenya, from its catchment and the trophic state of the lake. In: Harper DM, Boar R, Everard M, Hickley P (eds) Lake Naivasha, Kenya. Springer, Berlin, pp 73-80

30. Harper DM, Mavuti K (2004) Lake Naivasha, Kenya: ecohydrology to guide the management of a tropical protected area

31. Njiru J, Morara G, Waithaka E, Mugo J (2015) Fish kills in lake Naivasha, Kenya: what was the probable cause. Int J Fish Aquat Stud 3(1):179-184

32. Agutu PO, Gachari MK, Mundia CN (2018) An assessment of the role of water hyacinth in the water level changes of Lake Naivasha using GIS and remote sensing. Am J Remote Sens 6(2):74-88

33. Waithaka E, Priscilla B, Alice M, Anthony N, George M (2018) Assessment of macrophyte populations in Lake Naivasha, Kenya; using GIS and remote sensing. J Environ Pollut Manag 1:202

34. Stoof-Leichsenring KR, Junginger $A$, Olaka LA, Tiedemann $R$, Trauth MH (2011) Environmental variability in Lake Naivasha, Kenya, over the last two centuries. J Paleolimnol 45(3):353-367

35. Tarras-Wahlberg H, Everard M, Harper DM (2002) Geochemical and physical characteristics of river and lake [2pt] sediments at Naivasha, Kenya. Hydrobiologia 488(1-3):27-41

36. Kamau JN, Gachanja A, Ngila C, Kazungu JM, Gatagwu J (2007) The seasonal and spatial variations of labile copper, iron, manganese, lead and zinc sediment fractions in Lake Naivasha, Kenya. Lakes Reserv Res Manag 12(4):303-313

37. Mutia T, Virani M, Moturi W, Muyela B, Mavura W, Lalah J (2012) Copper, lead and cadmium concentrations in surface water, sediment and fish, C. Carpio, samples from Lake Naivasha: 
effect of recent anthropogenic activities. Environ Earth Sci 67(4):1121-1130

38. Otachi EO, Körner W, Avenant-Oldewage A, Fellner-Frank C, Jirsa F (2014) Trace elements in sediments, blue spotted tilapia Oreochromis leucostictus (Trewavas, 1933) and its parasite Contracaecum multipapillatum from Lake Naivasha, Kenya, including a comprehensive health risk analysis. Environ Sci Pollut Res 21(12):7339-7349

39. Hickley P, Bailey R, Harper DM, Kundu R, Muchiri M, North R et al (2002) The status and future of the Lake Naivasha fishery, Kenya. Hydrobiologia 488(1-3):181-190

40. Yihdego $Y$, Becht $R$ (2013) Simulation of lake-aquifer interaction at Lake Naivasha, Kenya using a three-dimensional flow model with the high conductivity technique and a DEM with bathymetry. J Hydrol 503:111-122

41. Nicholson SE. A review of climate dynamics and climate variability in Eastern Africa. The limnology, climatology and paleoclimatology of the East African lakes. 1996:25-56

42. Nicholson SE (2017) Climate and climatic variability of rainfall over eastern Africa. Rev Geophys 55(3):590-635

43. Onywere S, Shisanya C, Obando J, Ndubi A, Masiga D, Irura Z, et al., editors. Geospatial Extent of 2011-2013 Flooding from the Eastern African Rift Valley Lakes in Kenya and its Implication on the Ecosystems. international workshop on the soda lakes of Kenya: their current conservation status and management Naivasha; 2013

44. Obando JA, Onywere S, Shisanya C, Ndubi A, Masiga D, Irura Z et al (2016) Impact of short-term flooding on livelihoods in the Kenya Rift Valley Lakes. In: Meadows M, Lin JC (eds) Geomorphology and society. Springer, Berlin, pp 193-215

45. Everard M, Harper DM (2002) Towards the sustainability of the Lake Naivasha Ramsar site and its catchment. Hydrobiologia 488(1-3):191-203

46. Otieno PO, Owuor PO, Lalah JO, Pfister G, Schramm K-W (2013) Impacts of climate-induced changes on the distribution of pesticides residues in water and sediment of Lake Naivasha, Kenya. Environ Monit Assess 185(3):2723-2733

47. Otieno P, Okinda Owuor P, Lalah J, Pfister G, Schramm K-W (2015) Monitoring the occurrence and distribution of selected organophosphates and carbamate pesticide residues in the ecosystem of Lake Naivasha, Kenya. Toxicol Environ Chem 97(1):51-61

48. Gitahi S, Harper D, Muchiri S, Tole M (2002) Organochlorine and organophosphorus pesticide concentrations in water, sediment, and selected organisms in Lake Naivasha (Kenya). Hydrobiologia 488(1-3):123-128

49. Towett EK, Shepherd KD, Cadisch G (2013) Quantification of total element concentrations in soils using total X-ray fluorescence spectroscopy (TXRF). Sci Total Environ 463:374-388

50. Nocita M, Stevens A, van Wesemael B, Aitkenhead M, Bachmann $M$, Barthès $B$ et al (2015) Soil spectroscopy: an alternative to wet chemistry for soil monitoring. Adv Agron 132:139-159

51. Jakubek DJ, Forsythe KW (2004) A GIS-based kriging approach for assessing Lake Ontario sediment contamination. Great Lakes Geogr 11(1):1-14

52. Muller G (1969) Index of geoaccumulation in sediments of the Rhine River. GeoJournal 2:108-118

53. Wedepohl KH (1995) The composition of the continental crust. Geochim Cosmochim Acta 59(7):1217-1232

54. Salomons W, Förstner U (1984) Metals in the hydrocycle. Springer, Berlin

55. Abrahim G, Parker R, Nichol S (2007) Distribution and assessment of sediment toxicity in Tamaki Estuary, Auckland, New Zealand. Environ Geol 52(7):1315-1323

56. Jafarabadi AR, Bakhtiyari AR, Toosi AS, Jadot C (2017) Spatial distribution, ecological and health risk assessment of heavy metals in marine surface sediments and coastal seawaters of fringing coral reefs of the Persian Gulf, Iran. Chemosphere 185:1090-1111

57. Elkady AA, Sweet ST, Wade TL, Klein AG (2015) Distribution and assessment of heavy metals in the aquatic environment of Lake Manzala, Egypt. Ecol Ind 58:445-457

58. Iqbal J, Saleem M, Shah MH (2016) Spatial distribution, environmental assessment and source identification of metals content in surface sediments of freshwater reservoir, Pakistan. Chem Erde-Geochem 76(1):171-177

59. Birch GF, Olmos MA (2008) Sediment-bound heavy metals as indicators of human influence and biological risk in coastal water bodies. ICES J Mar Sci 65(8):1407-1413

60. Liao J, Chen J, Ru X, Chen J, Wu H, Wei C (2017) Heavy metals in river surface sediments affected with multiple pollution sources, South China: distribution, enrichment and source apportionment. J Geochem Explor 176:9-19

61. Zheng-Qi X, Shi-Jun N, Xian-Guo T, Cheng-Jiang Z (2008) Calculation of heavy metals' toxicity coefficient in the evaluation of potential ecological risk index. Environ Sci Technol 2(8):31

62. Kang X, Song J, Yuan H, Duan L, Li X, Li N et al (2017) Speciation of heavy metals in different grain sizes of Jiaozhou Bay sediments: bioavailability, ecological risk assessment and source analysis on a centennial timescale. Ecotoxicol Environ Saf 143:296-306

63. Bai J, Huang L, Yan D, Wang Q, Gao H, Xiao R et al (2011) Contamination characteristics of heavy metals in wetland soils along a tidal ditch of the Yellow River Estuary, China. Stoch Env Res Risk Assess 25(5):671-676

64. Dai X, Zhou Y, Ma W, Zhou L (2017) Influence of spatial variation in land-use patterns and topography on water quality of the rivers inflowing to Fuxian Lake, a large deep lake in the plateau of southwestern China. Ecol Eng 99:417-428

65. Kumar SB, Padhi R, Mohanty A, Satpathy K (2017) Elemental distribution and trace metal contamination in the surface sediment of south east coast of India. Mar Pollut Bull 114(2):1164-1170

66. Cardoso AG, Boaventura GR, Silva Filho EV, Brod JA (2001) Metal distribution in sediments from the Ribeira Bay, Rio de JaneiroBrazil. J Braz Chem Soc 12(6):767-774

67. Boar R, Harper DM (2002) Magnetic susceptibilities of lake sediment and soils on the shoreline of Lake Naivasha, Kenya. In: Harper DM, Boar RR, Everard M, Hickley P (eds) Lake Naivasha, Kenya. Berlin, Springer, pp 81-88

68. Redwan M, Elhaddad E (2017) Heavy metals seasonal variability and distribution in Lake Qaroun sediments, El-Fayoum, Egypt. J Afr Earth Sc 134:48-55

69. Kishe M, Machiwa J (2003) Distribution of heavy metals in sediments of Mwanza Gulf of Lake Victoria, Tanzania. Environ Int 28(7):619-625

70. Varol M, Şen B (2012) Assessment of nutrient and heavy metal contamination in surface water and sediments of the upper Tigris River, Turkey. CATENA 92:1-10

71. Goher ME, Farhat HI, Abdo MH, Salem SG (2014) Metal pollution assessment in the surface sediment of Lake Nasser, Egypt. Egypt J Aquat Res 40(3):213-224

72. Chen C-W, Kao C-M, Chen C-F, Dong C-D (2007) Distribution and accumulation of heavy metals in the sediments of Kaohsiung Harbor, Taiwan. Chemosphere 66(8):1431-1440

73. Christophoridis C, Dedepsidis D, Fytianos K (2009) Occurrence and distribution of selected heavy metals in the surface sediments of Thermaikos Gulf, N. Greece. Assessment using pollution indicators. J Hazard Mater 168(2-3):1082-1091

74. Nirmala K, Ramesh R, Ambujam N, Arumugam K, Srinivasalu S (2016) Geochemistry of surface sediments of a tropical brackish water lake in South Asia. Environ Earth Sci 75(3):247 
75. Njenga J, Ramanathan A, Subramanian V (2009) Partitioning of heavy metals in the sediments of Lake Naivasha, Kenya. Chem Speciat Bioavailab 21(1):41-48

76. Förstner U (1976) Lake sediments as indicators of heavy-metal pollution. Naturwissenschaften 63(10):465-470

77. Ballot A, Kotut K, Novelo E, Krienitz L (2009) Changes of phytoplankton communities in Lakes Naivasha and Oloidien, examples of degradation and salinization of lakes in the Kenyan Rift Valley. Hydrobiologia 632(1):359-363

78. van Oel PR, Mulatu DW, Odongo VO, Meins FM, Hogeboom RJ, Becht $R$ et al (2013) The effects of groundwater and surface water use on total water availability and implications for water management: the case of Lake Naivasha, Kenya. Water Resour Manage 27(9):3477-3492

Publisher's Note Springer Nature remains neutral with regard to jurisdictional claims in published maps and institutional affiliations. 